Iğdır Üniversitesi Fen Bilimleri Enstitüsü Dergisi, 11(3): 1980-1989, 2021

Journal of the Institute of Science and Technology, 11(3): 1980-1989, 2021

Fizik / Physics

ISSN: 2146-0574, eISSN: 2536-4618

DOI: 10.21597/jist.857611

\section{Araştırma Makalesi / Research Article}

Geliş tarihi / Received: 10.01.2021

Atıf İçin: Üstündağ FD, Güngör E, Subaşat Kara H, 2021. Trifenilboroksin Katyonu ve $\mathrm{Pt}(\mathrm{SCN})_{4}$ Anyon Tuzu Tektonlarının Kombinasyonuna Dayanan Hidrojen Bağlı Ağların Sentezi ve Yapısal Özellikleri. Iğdır Üniversitesi Fen Bilimleri Enstitüsü Dergisi, 11(3): 1980-1989.

To Cite: Ustundag FD, Gungor E, Subasat Kara H, 2021. Synthesis and Structural Features of Hydrogen-Bonded Networks Based on The Combination of Tectons Triphenylboroxine Cation and $\mathrm{Pt}(\mathrm{SCN})_{4}$ Anion Salts. Journal of the Institute of Science and Technology, 11(3): 1980-1989.

\title{
Synthesis and Structural Features of Hydrogen-Bonded Networks Based on The Combination of Tectons Triphenylboroxine Cation and $\mathrm{Pt}(\mathrm{SCN})_{4}$ Anion Salts
}

\section{Fumet Duygu USTUNDAG ${ }^{1}$, Elif GUNGOR ${ }^{2}$, Hulya KARA SUBASAT ${ }^{3 *}$}

ABSTRACT: In this work, a new compound $\left[\mathrm{C}_{15} \mathrm{H}_{16} \mathrm{~B}_{3} \mathrm{~N}_{3} \mathrm{O}_{5}\right]$. $\left[\mathrm{Pt}(\mathrm{SCN})_{4}\right] \cdot 2\left(\mathrm{H}_{2} \mathrm{O}\right]$ (1) has been synthesized and structurally characterized. The compound (1) crystallizes in monoclinic, space group $\mathrm{P} 2{ }_{1} / \mathrm{c} a=10.443 \AA, \mathrm{b}=24.918 \AA, \mathrm{c}=15.048 \AA, \alpha=90^{\circ}, \beta=133.945^{\circ}, \gamma=90^{\circ}, \mathrm{V}=2819.4 \AA^{3}, \mathrm{Z}=4$. The use of molecular tecton (building block) able to form thiocyano-based hydrogen-bonded synthons $(\mathrm{OH} \cdots \mathrm{SCN})$ to synthesize a diverse range of crystal structures is described. In the crystal structure, molecules are linked by intermolecular $\mathrm{SCN} \cdots \mathrm{HN}$ and $\mathrm{BO} \cdots \mathrm{HN}$ hydrogen bonds, forming a threedimensional network.

Keywords: Boroxine compound, single-crystal structure, hydrogen bonds synthons, supramolecular frameworks.

\footnotetext{
${ }^{1}$ Fumet Duygu USTUNDAG (Orcid ID: 0000-0001-5290-8924), Marmara University, Faculty of Medicine, Department of Biophysics, Istanbul, Turkey

${ }^{2}$ Elif GUNGOR (Orcid ID: 0000-0002-7158-9604), Balikesir University, Faculty of Science and Art, Department of Physics, Balikesir, Turkey

${ }^{3}$ Hulya KARA SUBASAT (Orcid ID: 0000-0002-2032-8930), Mugla Sitk1 Kocman University, Graduate School of Natural and Applied Sciences, Department of Energy, Mugla, Turkey

*Sorumlu Yazar/Corresponding Author: Hulya KARA SUBASAT, e-mail: hulyasubasat@mu.edu.tr

This study was produced from a part of Fumet Duygu USTUNDAG's Master's thesis. A part of the article was presented as a poster at the "Adım Physics Days III" held in Isparta on 17-18 April 2014.
} 


\section{INTRODUCTION}

In recent years, boronic acid compounds have been widely used in pharmaceuticals, agrochemicals, sensors for carbohydrates, optical and electrochemical sensors, biologically relevant materials, cell manipulation, including capture, culture, and protection of cells, inhibitors of proteases, therapeutic agents, enzyme inhibitors ( Pedireddi and SeethaLekshmi, 2004; Kara et al., 2006; Dai et al., 2010; Whyte et al., 2013; Brooks and Sumerlin, 2016). They are also used in the treatment of cancer with boron neutron capture therapy (BNCT), tumors, HIV, obesity, and diabetes in medicine ( Yang et al., 2003; Cambre and Sumerlin, 2011; Brooks and Sumerlin, 2016). Substituted pyridines are important components of drug candidates (Cai et al., 2002). The first boronic acid-containing anticancer agent Velcade proves increased interest in boronic acid in medicine (Hall, 2011). Boronic acids are rich in hydrogen bond derivatives and perform a wide variety of cross-coupling reactions with metals. Due to these properties, they have attracted great attention and gain importance in supramolecular chemistry (Aakeröy et al., 2005; Hall, 2011). At the same time, boronic acids are important compounds in the definition of molecules and anions in material science and crystal engineering (Braga et al., 2003; Deplano et al., 2004; Aakeröy and Salmon, 2005; Marinaro et al., 2012; Hezil, 2016). Boronic acid compounds are promising buildingblocks in crystal engineering, mostly due to the formation of hydrogen bonds that seems to be the main force in producing supramolecular species in the solid phase ( Hall, 2011; Campos-Gaxiola et al., 2017). Ortho-substituted boronic acids seem to be especially prone to the creation of supramolecular structures. Boronic acids are useful building-blocks in the design and synthesis of supramolecular assemblies ( Aakeröy et al., 2005; Yahsi et al., 2015; Neochoritis et al., 2019). Water molecules play an important role as spacer molecules in the resulting supramolecular structure (Rodríguez-Cuamatzi et al., 2009).

Formation of boroxines or/and N-B dative bonds is also useful in crystal engineering (Aakeröy et al., 2005). Boroxines are cyclic trimers of organoboronic acids produced by dehydration of the acids. Boronic acids easily undergo spontaneous dehydration that can take place at purifying conditions or under storage, resulting in cyclic boroxines (Korich and Iovine, 2010; Hall, 2011). Due to this fact, most of the market-available boronic acids contain various amounts of anhydride. As the suppliers claim, the "impurity" does not disqualify the product as the dehydration process is reversible and therefore boronic acids and boroxines can be used interchangeably in most cases ( Rodríguez-Cuamatzi et al., 2009; Hall, 2011) .

For the past few years, our research group has been actively working on the structural and optical characterization of organic molecules containing various aromatic carboxylate and pyridine derivatives (Erkarslan et al., 2016; Coban et al., 2016; Kocak et al., 2017; Erkarslan et al., 2018). We have also reported geometrical and structural features of compounds formatting between pyridinium and bipyridinium cationic tectons and $\left[\mathrm{PtCl}_{4}\right]^{-2},\left[\mathrm{PdCl}_{4}\right]^{-2},\left[\mathrm{PtCl}_{6}\right]^{-2}$ anionic salts (Kara et al., 2006; 2011). These studies showed that caused the $1 \mathrm{D}, 2 \mathrm{D}$ and $3 \mathrm{D}$ networks formation according to the hydrogen bond donor ability of cations due to the isometric and isosteric use of 4-pyridinium cation. It was reported that it played an important role in determining their structure of stereochemistry of hydrogen bond donor groups in cations and caused different behaviours.

In this study, we have synthesized a new compound $\left[\mathrm{C}_{15} \mathrm{H}_{16} \mathrm{~B}_{3} \mathrm{~N}_{3} \mathrm{O}_{5}\right]$. $\left[\mathrm{Pt}(\mathrm{SCN})_{4}\right] \cdot 2\left(\mathrm{H}_{2} \mathrm{O}\right)(\mathbf{1})$ with the salt of the $\left[\mathrm{Pt}(\mathrm{SCN})_{4}\right]^{-2}$ anion and dehydration of 4-Pyridine boronic acid to boroxine. We explored the use of molecular tecton of thiocyano-based hydrogen-bonded synthons (Pt-SCN $\cdots \mathrm{HO}$, $\mathrm{SCN} \cdots \mathrm{HN}$ and $\mathrm{BO} \cdots \mathrm{HN}$ ) to synthesis a diverse range of crystal structure. 


\section{MATERIALS AND METHODS}

\section{Materials and Measurements}

$\left[\mathrm{C}_{15} \mathrm{H}_{16} \mathrm{~B}_{3} \mathrm{~N}_{3} \mathrm{O}_{5}\right]$. $\left[\mathrm{Pt}(\mathrm{SCN})_{4}\right] .2\left(\mathrm{H}_{2} \mathrm{O}\right)(\mathbf{1})$ was synthesized according to the published experimental method (Kara et. al., 2006). The organic compound was recrystallized from concentrated hydrochloric acid to give hydrochloride salts. Single crystal of 1 was obtained by slow diffusion of in stoichiometric quantities of boroxine and metal $\left[\mathrm{Pt}(\mathrm{SCN})_{4}\right]$ salt reagent. Elemental analysis was performed in the Microanalytical Service of the Chemistry School.

\section{Synthesis of [(4- $\left.\left.\mathrm{HNC}_{5} \mathrm{H}_{4}\right)_{3} \mathrm{~B}_{3} \mathrm{O}_{3}\right]$, Boroxine}

4-Pyridinylboronic acid, (1 mmol) was dissolved in $\% 37$ hydrochloric acid solution and water. The solution was maintained at the boiling point with stirring for $1 \mathrm{~h}$. The solvent was evaporated, and the white crystals were obtained upon filtration. The dehydration of 4-Pyridine boronic acid to boroxine is outlined in Scheme 1.

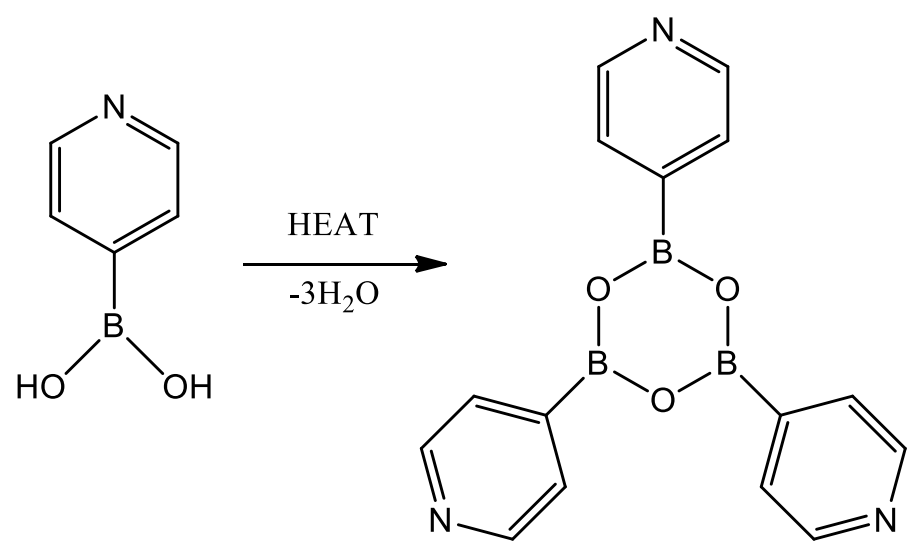

Scheme 1 The dehydration of 4-Pyridine boronic acid to boroxine

\section{Synthesis of $\left[\mathrm{C}_{15} \mathrm{H}_{16} \mathrm{~B}_{3} \mathrm{~N}_{3} \mathrm{O}_{5}\right]$.[ $\left.\mathrm{Pt}(\mathrm{SCN})_{4}\right] .2\left(\mathrm{H}_{2} \mathrm{O}\right]$}

To a solution of $\mathrm{Pt}(\mathrm{SCN})_{4}(0.4274 \mathrm{mg}, 1 \mathrm{mmol})$ in $10 \mathrm{ml}$ of water, a solution of [(4$\left.\left.\mathrm{HNC}_{5} \mathrm{H}_{4}\right)_{3} \mathrm{~B}_{3} \mathrm{O}_{3}\right](0.1229 \mathrm{~g}, 1 \mathrm{mmol})$ in $10 \mathrm{ml}$ water was added dropwise with stirring. The orange precipitate was obtained, collected by filtration and dried. The synthetic route of $\mathbf{1}$ is outlined in Scheme 2. Yield: 55\%. Elemental analysis (\%). Found: C, 27.89; H, 2.61; N, 12.01. Calculated: C, $27.99 ; \mathrm{H}, 2.59 ; \mathrm{N}, 12.03$.

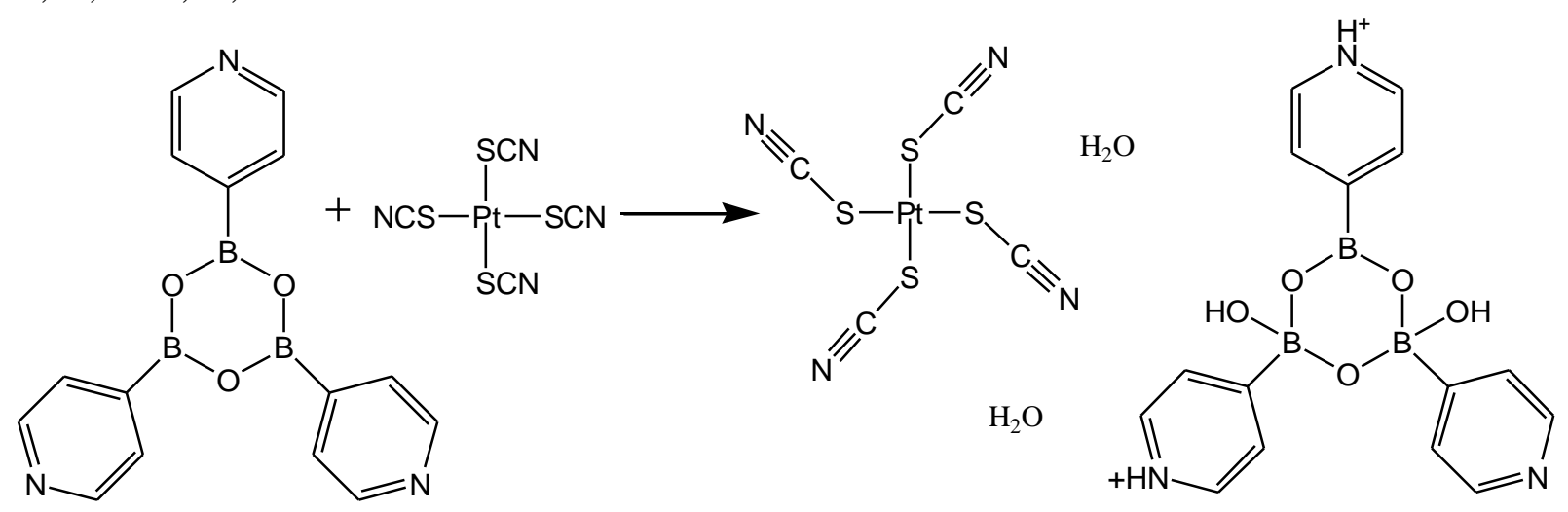

Scheme 2. The synthetic route of $\mathbf{1}$ 


\section{X-Ray Crystallography}

Diffraction measurements were made on three-circle Bruker Apex II Kappa CCD diffractometers using graphite monochromated Mo- $\mathrm{K}_{\alpha}$ radiation $(\lambda=0.71073 \AA)$ at $100 \mathrm{~K}$ for $\mathbf{1}$. The intensity data were integrated using the SAINT ( Bruker-AXS, 2008) program. The data was collected for Lorentzpolarization and absorption effects (Sheldrick, 2008). Absorption corrections were applied based on equivalent reflections using SADABS (Sheldrick, 2008). The structures were solved by direct methods using SHELXS (Sheldrick, 2008) and were refined with SHELXL (Sheldrick, 2015) using full-matrix least-squares in Olex2 (Dolomanov et al., 2009) program. All non-hydrogen atoms were assigned anisotropic displacement parameters and refined without positional constraints. Hydrogen atoms were included in idealized positions. Crystal data for $\mathbf{1}$ and its structural refinement parameters are given in Table 1.

Table 1 Crystal data of 1

\begin{tabular}{lc}
\hline & $\mathbf{1}$ \\
\hline CCDC deposit no. & 1993503 \\
Chemical Formula & $\mathrm{C}_{15} \mathrm{H}_{16} \mathrm{~B}_{3} \mathrm{~N}_{3} \mathrm{O}_{5} \mathrm{C}_{4} \mathrm{~N}_{4} \mathrm{PtS}_{4} .2\left(\mathrm{H}_{2} \mathrm{O}\right)$ \\
Crystal System & Monoclinic \\
Space Group & $\mathrm{P} 2{ }_{1} / \mathrm{c}$ \\
& $a=10.443(2) \AA$ \\
& $b=24.918(5) \AA$ \\
Unit cell parameters & $c=15.048(4) \AA$ \\
& $\alpha=90^{\circ}$ \\
V & $\beta=133.945(17)^{\circ}$ \\
$\mathrm{T}$ & $\gamma=90^{\circ}$ \\
$\mathrm{Z}$ & $2819.4(14) \AA^{3}$ \\
$\mu$ & $100 \mathrm{~K}$ \\
Reflections collected & 4 \\
Independent reflections $\left(\mathrm{R}_{\text {int }}\right)$ & $5.327 \mathrm{~mm}^{-1}$ \\
Final R $\mathrm{R}_{1}[\mathrm{I}>2 \sigma(\mathrm{I})]$ & 19798 \\
\hline
\end{tabular}

\section{RESULTS AND DISCUSSION}

Molecular networks are infinite periodic molecular formed under self-assembly conditions between molecular tectons. To create hydrogen bonded 1D, 2D, 3D networks, it is necessary to combine anionic and cationic components. When hydrogen bonding acceptor thiocyanometallate anions and metal centers are combined, they exhibit interesting coordination modes leading to various H-bond patterns (Sheldrick, 2015). Although thiocyanometallate anions and cyanometallate analogs are different sizes and geometries, they are similar hydrogen bonding properties (Figure 1). Although the isothiocyanometallate complexes and cyanometallate anions as $\mathrm{H}$-bond acceptors have similar coordination geometry, nevertheless they offer different possibilities ( Bowmaker et al., 2009; Tan et al., 2013; Otgonbaatar et al., 2015). 


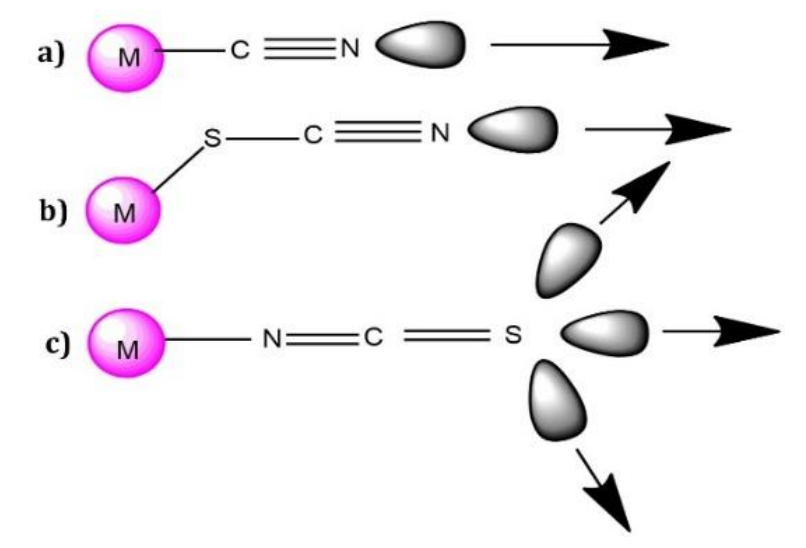

Figure 1. Coordination and possible H-bond acceptor modes of cyanide (a) thiocyanate (b) and isothiocyanate (c) metal complexes. The arrow represents the direction of the H-bond.

Compound 1 crystallizes in the monoclinic crystal system and $\mathrm{P} 2{ }_{1} / \mathrm{c}$ space group. The asymmetric unit of compound contains a $\left[\mathrm{Pt}(\mathrm{SCN})_{4}\right]^{-2}$ anion, a boroxine, and two water molecules (Figure 2). The Pt ion in the $\mathbf{1}$ is four-coordinated by four SCN bounds and located on an inversion centre. The cis S-Pt-S bond angles are between 83.28(11) and $95.25(12)^{\circ}$ for 1 which deviates from the ideal square geometry angle $\left(90^{\circ}\right)$. Therefore, $\left[\mathrm{Pt}(\mathrm{SCN})_{4}\right]^{-2}$ anion of $\mathbf{1}$ have slightly distorted square planar geometry around the Pt centre with the average Pt-S bond lengths of 2.32(7) $\AA$. The average $\mathrm{Pt}-\mathrm{C}$ and $\mathrm{C} \equiv \mathrm{N}$ bond lengths of compounds are 1.68(8) $\AA$ and 1.15(10) $\AA$, respectively. The S-Pt-S angle varies from 1 is between $83.28(11)^{\circ}$ and $95.25(12)^{\circ}$. As shown in Table 2, the Pt-S bond is bent with the PtSC angle varying between $101.30(3)^{\circ}$ and $109.60(5)^{\circ}$. The NCS angle in the thiocyanide anion of $\mathbf{1}$ is almost linear with an average $177.30(8)^{\circ}$.

The triphenylboroxin in $\mathbf{1}$ contains one three-coordinate, two four-coordinate boron. The phenyl rings attached to the three-coordinate $\mathrm{B}$ atom in the triphenylboroxin structure of $\mathbf{1}$ is approximately coplanar with the $\mathrm{B}_{3} \mathrm{O}_{3}$ ring. The average $\mathrm{B}-\mathrm{O}-\mathrm{B}$ bond angles in the $\mathrm{B}_{3} \mathrm{O}_{3}$ ring of 1 is $124.25(10)^{\circ}$ which are display deviates from $120^{\circ}$ values expected if the bonds are formed from $\mathrm{sp}^{2}$ hybrid orbitals. The four-coordinate $\mathrm{B}$ atoms in the $\mathrm{B}_{3} \mathrm{O}_{3}$ rings of $\mathbf{1}$ is distorted from planarity, resulting in the formation of two twisted six-membered rings after coordination with $\mathrm{OH}$ of $\mathrm{B}$ atoms. Therefore, the three-coordinate boron atom has slightly distorted trigonal planar geometry while the four-coordinate boron atoms have slightly distorted tetrahedral geometry.

Compound 1 is formed 1-D chain as infinite ribbons by the mutual interconnection of the cationic and anionic units with hydrogen bonds as shown in Figure 3a. The four ends of the $[\mathrm{Pt}(\mathrm{SCN}) 4]^{2-}$ anion of both compounds are linked to four cations by one Pt-SCN $\cdots \mathrm{HO}$ (boroxine) and three Pt-SCN $\cdots \mathrm{HO}$ (water) hydrogen bonds. The Pt-SCN $\cdots \mathrm{HO}$ (boroxine) and Pt-SCN $\cdots \mathrm{HO}$ (water) distances are $2.838 \AA$ and $2.887 \AA$ for $\mathbf{1}$ and formed these hydrogen bonds are strong.

The $1 \mathrm{D}$ chain of $\mathbf{1}$ are arranged as double ribbons in the $a b$ plane from the interconnection of dications and dianions with $\mathrm{O}-\mathrm{H} \cdots \mathrm{O}$ hydrogen bonds, forming $2 \mathrm{D}$ networks (Table 3, Figure $3 \mathrm{~b}$ ). In the structure, 2D sheets are packed in parallel in the $a b$ plane. The distance between two metal centres within the 1-D networks is $10.443 \AA$ for $\mathbf{1}$ while the distance between two metal centres belonging to two serial chains is observed $12.511 \AA$ for 1. Additionally, ribbon motifs with $\mathrm{SCN} \cdots \mathrm{HN}$ and $\mathrm{BO} \cdots \mathrm{HN}$ hydrogen bond interactions can increase the stability of solid-state structure and form 3D networks (Figure 4). 


\section{6}

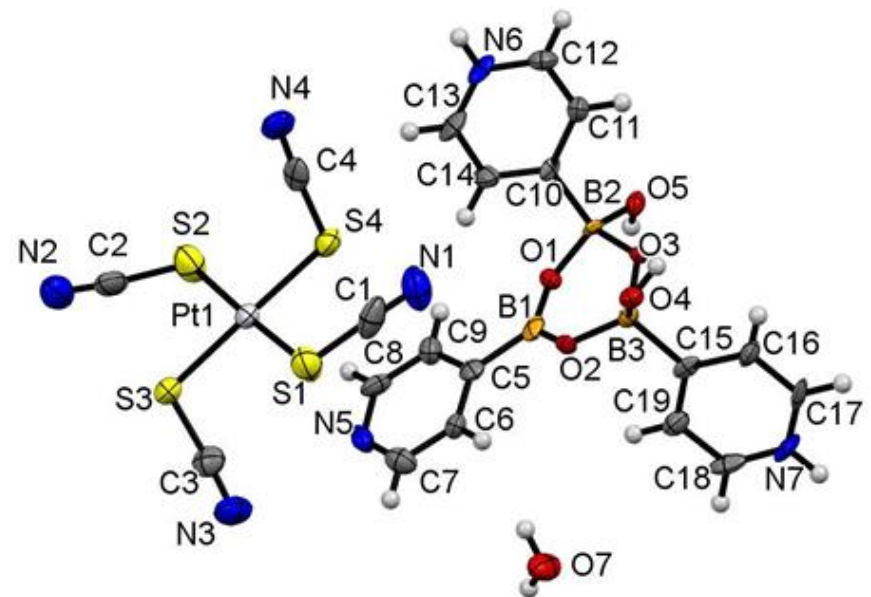

Figure 2. The molecular structure of $\mathbf{1}$.

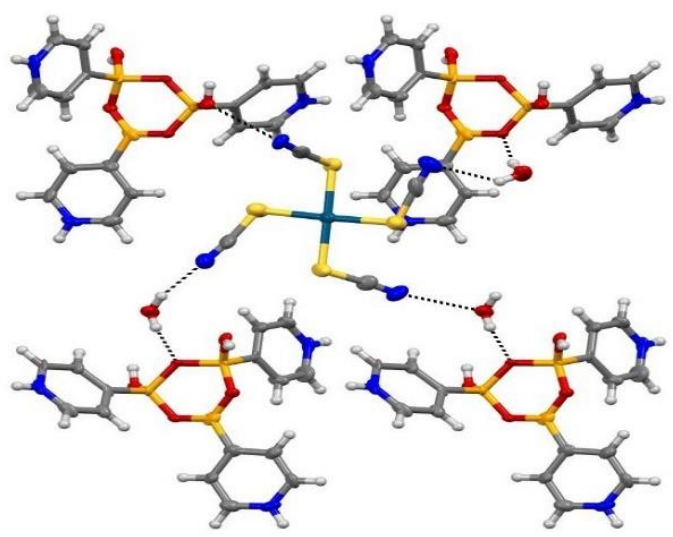

(a)

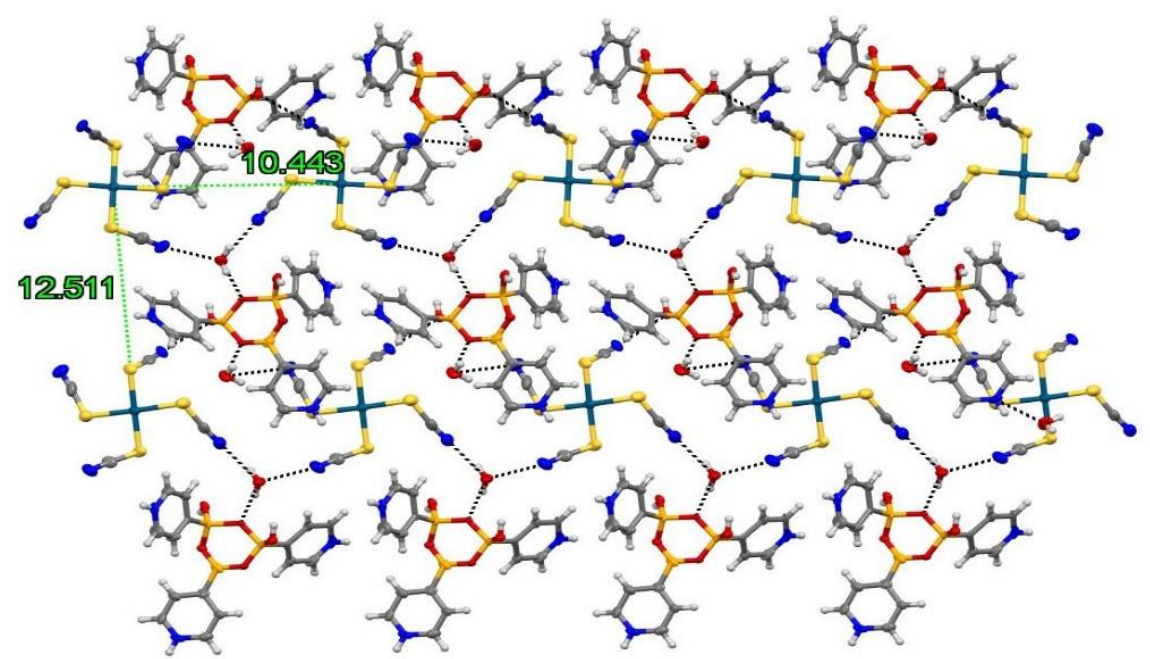

(b)

Figure 3. (a) Part of the crystal structure of formed between $\left[\mathrm{Pt}(\mathrm{SCN})_{4}\right]^{2-}$ anion and boroxine cation (b) $2 \mathrm{D}$ sheets of Pt-SCN $\cdots \mathrm{HO}$ (boroxine) and $\mathrm{Pt}-\mathrm{SCN} \cdots \mathrm{HO}$ (water) hydrogen bonded double ribbons in the structure. 


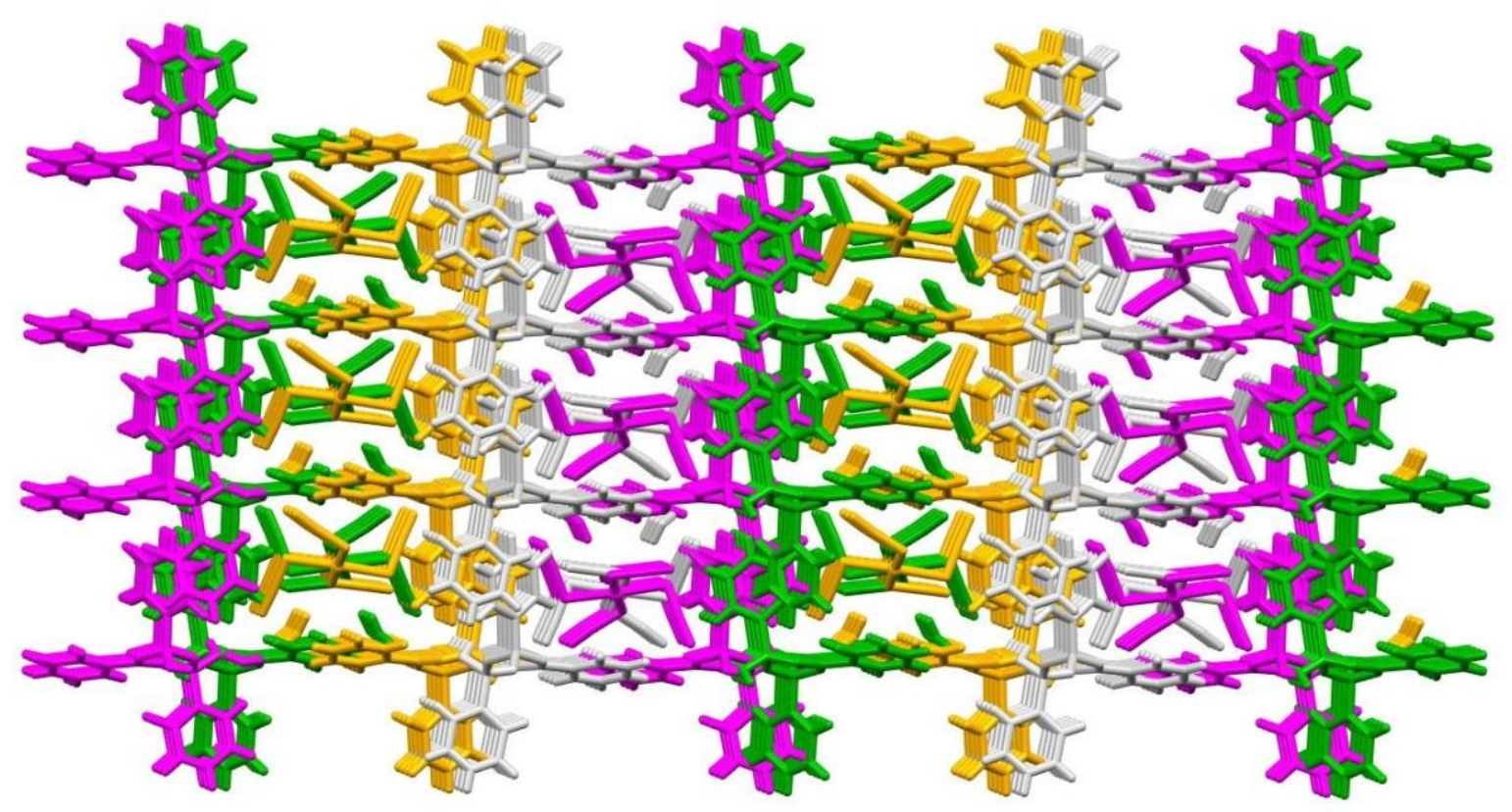

Figure 4. 3-D packed structure of $\mathrm{SCN} \cdots \mathrm{HN}$ and $\mathrm{BO} \cdots \mathrm{HN}$ hydrogen-bonded ribbons of 1.

Table 2. Some bond lengths $(\AA)$ and angles $\left(^{\circ}\right)$ for $\mathbf{1}$

\begin{tabular}{llll}
\hline Bond lengths $(\AA)$ & & & \\
\hline Pt1-S1 & $2.297(5)$ & O1-B2 & $1.459(9)$ \\
Pt1-S2 & $2.315(5)$ & O2-B1 & $1.345(16)$ \\
Pt1-S3 & $2.312(2)$ & O2-B3 & $1.462(14)$ \\
Pt1-S4 & $2.329(2)$ & O3-B2 & $1.511(16)$ \\
S1-C1 & $1.688(11)$ & O3-B3 & $1.541(14)$ \\
S2-C2 & $1.689(13)$ & N1-C1 & $1.133(16)$ \\
S3-C3 & $1.690(15)$ & N2-C2 & $1.134(18)$ \\
S4-C4 & $1.664(13)$ & N3-C3 & $1.144(19)$ \\
O1-B1 & $1.365(13)$ & N4-C4 & $1.168(16)$ \\
\hline Bond angles $\left(^{\circ}\right)$ & & & \\
S2-Pt1-S4 & $83.28(11)$ & B1-O1-B2 & $121.20(8)$ \\
S3-Pt1-S4 & $176.99(10)$ & B1-O2-B3 & $124(8)$ \\
S1-Pt1-S3 & $86.85(12)$ & B2-O3-B3 & $127.20(7)$ \\
S1-Pt1-S4 & $94.68(11)$ & O1-B1-O2 & $124(9)$ \\
S1-Pt1-S2 & $177.62(9)$ & O2-B2-O3 & $108(8)$ \\
S2-Pt1-S3 & S1-C1-N1 & $107.60(1)$ \\
Pt1-S1-C1 & $95.25(12)$ & S2-C2-N2 & $176.30(1)$ \\
Pt1-S2-C2 & $107.10(5)$ & S3-C3-N3 & $174.30(1)$ \\
Pt1-S3-C3 & $109.60(5)$ & S4-C4-N4 & $176(10)$ \\
Pt1-S4-C4 & $103.40(4)$ & & $176.20(9)$ \\
\hline
\end{tabular}


Table 3. Hydrogen bond geometry $\left(\AA,^{\circ}\right)$ for $\mathbf{1}$.

\begin{tabular}{|c|c|c|c|c|c|}
\hline D-H...A* & D-H & 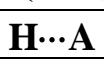 & D..A & D-H $\cdots A$ & Symmetry \\
\hline $\mathrm{O} 4-\mathrm{H} 4 \cdots \mathrm{N} 6$ & 0.84 & 2.38 & 2.661 & 100 & $1-x, 1-y, 1-z$ \\
\hline $\mathrm{N} 5-\mathrm{H} 5 \cdots \mathrm{O} 7$ & 0.88 & 2.01 & 2.729 & 138 & $\mathrm{x}, \mathrm{y}, 1+\mathrm{z}$ \\
\hline N5-H5 $\cdots$ N4 & 0.88 & 2.61 & 3.209 & 126 & $1+x, 3 / 2-y, 1 / 2+z$ \\
\hline O5-H5A $\cdots \mathrm{O} 1$ & 0.84 & 2.52 & 2.878 & 107 & $2-x, 1-y, 2-z$ \\
\hline N6-H6A $\cdots$ O4 & 0.88 & 1.80 & 2.661 & 164 & $1-x, 1-y, 1-z$ \\
\hline O6-H6C $\cdots \mathrm{N} 2$ & 0.87 & 2.06 & 2.829 & 147 & $-\mathrm{x},-1 / 2+\mathrm{y}, 3 / 2-\mathrm{z}$ \\
\hline N7-H7A $\cdots$ O5 & 0.88 & 1.81 & 2.661 & 163 & $3-x, 1-y, 2-z$ \\
\hline O7-H7B $\cdots$ N1 & 0.87 & 2.29 & 2.910 & 129 & $\mathrm{x}, 3 / 2-\mathrm{y},-1 / 2+\mathrm{z}$ \\
\hline $\mathrm{O} 7-\mathrm{H} 7 \mathrm{C} \cdots \mathrm{O} 2$ & 0.87 & 2.10 & 2.961 & 168 & $\mathrm{x}, 3 / 2-\mathrm{y},-1 / 2+\mathrm{z}$ \\
\hline $\mathrm{C} 11-\mathrm{H} 11 \cdots \mathrm{N} 2$ & 0.95 & 2.56 & 3.486 & 165 & $1-\mathrm{x},-1 / 2+\mathrm{y}, 3 / 2-\mathrm{z}$ \\
\hline $\mathrm{C} 12-\mathrm{H} 12 \cdots \mathrm{N} 1$ & 0.95 & 2.54 & 3.311 & 139 & $1-x, 1-y, 1-z$ \\
\hline $\mathrm{C} 14-\mathrm{H} 14 \cdots \mathrm{O} 1$ & 0.95 & 2.58 & 2.924 & 102 & \\
\hline 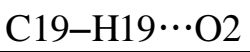 & 0.95 & 2.54 & 2.901 & 103 & \\
\hline
\end{tabular}

\section{CONCLUSION}

We have demonstrated the generation of hydrogen-bonded networks based on the combination of tectons triphenylboroxine cationic and $\mathrm{Pt}(\mathrm{SCN})_{4}$ anionic in crystal synthesis. The combination of the boroxine with thiocyanometallate $\mathrm{Pt}(\mathrm{SCN})_{4}$ leads to the formation of neutral, $1 \mathrm{D}$ and $2 \mathrm{D}, 3 \mathrm{D}$, periodic, H-bonded, infinite architectures. Based on structural features of the cationic and anionic partners, the infinite 1D networks by Pt-SCN $\cdots \mathrm{HO}$ (boroxine) and Pt-SCN $\cdots \mathrm{HO}$ (water) hydrogen bonds were formed. The formation of the 2D network resulted from the interconnection of dications and dianions through $\mathrm{O}-\mathrm{H} \cdots \mathrm{O}$ hydrogen. 3D networks were generated by the ribbon motifs with $\mathrm{SCN} \cdots \mathrm{HN}$ and $\mathrm{BO} \cdots \mathrm{HN}$ hydrogen bond interactions.

\section{ACKNOWLEDGEMENTS}

The authors thank to University of Balikesir (BAP-2013/23) for financial support, as well as Professor Guy Orpen (School of Chemistry, Bristol University, England) for the use of the X-ray diffractometer.

\section{Conflict of Interest}

The article authors declare that there is no conflict of interest between them.

\section{Author's Contributions}

The authors declare that they have contributed equally to the article.

\section{REFERENCES}

Aakeröy CB, Desper J and Levin B, 2005. Crystal Engineering Gone Awry and The Emergence of The Boronic Acid-Carboxylate Synthon. CrystEngComm, 7: 102-107.

Aakeröy CB and Salmon DJ, 2005. Building Co-crystals with Molecular Sense and Supramolecular Sensibility. CrystEngComm, 7: 439-448.

Bowmaker GA, Pakawatchai C, Saithong S, Skelton BW and White AH, 2009. 1:1 Complexes of Silver(i) thiocyanate with (substituted) Thiourea Ligands. Dalton Transactions, 14: 2588-2598.

Braga D, Polito M, Bracaccini M, D’Addario D, Tagliavini E, Sturba L and Grepioni F, 2003. Novel Organometallic Building Blocks for Molecular Crystal Engineering. 2. Synthesis and Characterization of Pyridyl and Pyrimidyl Derivatives of Diboronic Acid, $\left[\mathrm{Fe}\left(\eta 5-\mathrm{C}_{5} \mathrm{H}_{4}-\right.\right.$ $\left.\left.\mathrm{B}(\mathrm{OH})_{2}\right)_{2}\right]$, and of Pyridyl Boronic Acid, $\left[\mathrm{Fe}\left(\eta 5-\mathrm{C}_{5} \mathrm{H}_{4}-4-\mathrm{C}_{5} \mathrm{H}_{4} \mathrm{~N}\right)\left(\eta 5-\mathrm{C}_{5} \mathrm{H}_{4}-\right.\right.$ 
$\left.\left.\mathrm{B}(\mathrm{OH})_{2}\right)\right]$.Organometallics, 22: 2142-2150.

Brooks WLA and Sumerlin BS, 2016. Synthesis and Applications of Boronic Acid-Containing Polymers: From Materials to Medicine. Chemical Reviews, 116: 1375-1397.

Cai D, Larsen, RD and Reider PJ, 2002. Effective Lithiation of 3-Bromopyridine: Synthesis of 3Pyridine Boronic Acid and Variously 3-Substituted Pyridines. Tetrahedron Letters, 43: 42854287.

Cambre JN and Sumerlin BS, 2011. Biomedical Applications of Boronic Acid Polymers. Polymer, 52: 4631-4643.

Campos-Gaxiola JJ, García-Grajeda BA, Hernández-Ahuactzi IF, Guerrero-Álvarez JA, Höpfl H and Cruz-Enríquez A, 2017. Supramolecular Networks in Molecular Complexes of Pyridine Boronic Acids and Polycarboxylic Acids: Synthesis, Structural Characterization and Fluorescence Properties. CrystEngComm, 19: 3760-3775.

Coban MB, Erkarslan U, Oylumluoglu G, Aygun M and Kara H, 2016. Hydrothermal synthesis, crystal structure and Photoluminescent properties; 3D Holmium(III) coordination polymer. Inorganica Chimica Acta, 447: 87-91.

Dai C, Cheng Y, Cui J and Wang B, 2010. Click Reactions and Boronic Acids: Applications, Issues and Potential Solutions. Molecules, 15: 5768-5781.

Deplano P, Mercuri ML, Marchiò L, Pilia L, Salidu M, Serpe A and Tronci E, 2004. Salts of Cationic Platinum Dithiolenes with Anionic Platinum Complexes. Structural Characterization of $\left[\mathrm{Pt}\left(\mathrm{Me}_{2}\right.\right.$ pipdt) 2$]\left[\mathrm{Pt}(\mathrm{SCN})_{4}\right] \quad(\mathrm{Me} 2$ pipdt=N,N'-dimethyl-piperazine-2,3-dithione). Inorganica Chimica Acta, 357: 1608-1612.

Dolomanov OV, Bourhis LJ, Gildea RJ, Howard, JAK and Puschmann H, 2009. OLEX2: A Complete Structure Solution, Refinement and Analysis Program. Journal of Applied Crystallography, 42: 339-341.

Erkarslan U, Oylumluoglu G, Coban MB, Ozturk E and Kara H, 2016. Cyanide-bridged trinuclear $\mathrm{Mn}^{\mathrm{III}}-\mathrm{Fe}^{\mathrm{III}}$ assembly: Crystal structure, magnetic and photoluminescence behavior. Inorganica Chimica Acta, 445: 57-61.

Erkarslan U, Donmez A, Kara H, Aygun M and Coban MB, 2018. Synthesis, Structure and Photoluminescence Performance of a New Er3+ Cluster-Based 2D Coordination Polymer. Journal of Cluster Science, 29: 1177-1183.

Hall DG, 2011. Boronic Acids: Preparation and Applications in Organic Synthesis, Medicine and Materials 2 Volume Set, 2nd Completely Revised Edition.

Hezil H, 2016. Preparation, Structural and Thermal Studies of Boroxine Adducts Having Aryl Boronic Acids and Pyrazoles. African Journal of Pure and Applied Chemistry, 10: 42-55.

Kara H, Adams CJ, Orpen AG and Podesta TJ, 2006. Pyridinium Boronic Acid Salts in Crystal Synthesis. New Journal of Chemistry, 30: 1461-1469.

Kara H, Adams CJ, Schwarz B and Orpen AG, 2011. The Use of $\left[\mathrm{Fe}(\text { dithiooxalate })_{2}(\mathrm{NO})\right]^{2-}$ as a Tecton in Crystal Engineering. CrystEngComm, 13: 5082-5087.

Kocak C, Oylumluoglu G, Donmez A, Coban MB, Erkarslan U, Aygun M and Kara H, 2017. Crystal structure and photoluminescence properties of a new monomeric copper (II) complex: bis (3$\left\{\left[(3\right.\right.$-hydroxypropyl) imino] methyl $\}$-4-nitrophenolato- $\left.\kappa 3 \mathrm{O}, \mathrm{N}, \mathrm{O}^{\prime}\right)$ copper (II). Acta Crystallographica Section C: Structural Chemistry, 73: 414-419.

Korich AL and Iovine PM, 2010. Boroxine Chemistry and Applications: A Perspective. Dalton Transactions, 39: 1423-1431.

Marinaro WA, Schieber LJ, Munson EJ, Day VW and Stella VJ, 2012. Properties of A Model Aryl Boronic Acid and Its Boroxine. Journal of Pharmaceutical Sciences, 101: 3190-3198.

Neochoritis CG, Shaabani S, Ahmadianmoghaddam M, Zarganes-Tzitzikas T, Gao L, Novotná M, Mitríková T, Romero AR, Irianti MI, Xu R, Olechno J, Ellson R, Helan V, Kossenjans M, Groves MR and Dömling A, 2019. Rapid Approach to Complex Boronic Acids. Science Advances, 5: 1-9.

Otgonbaatar E, Chung MC, Umakoshi K and Kwak CH, 2015. Preparation and Luminescent Property 
of the Self-Assembled Nanoscale Network Systems Combined Tetracyanoplatinate(II) and Copper(II)-Polyaza Complexes. Journal of Nanoscience and Nanotechnology, 15: 1389-1395.

Pedireddi, VR and SeethaLekshmi N, 2004. Boronic Acids in The Design and Synthesis of Supramolecular Assemblies. Tetrahedron Letters, 45: 1903-1906.

Rodríguez-Cuamatzi P, Luna-garcía R, Torres-huerta A, Bernal-Uruchurtu, MI, Barba V and Höpfl H, 2009. On the Organizing Role of Water Molecules in the Assembly of Boronic Acids and 4,4'Bipyridine: 1D, 2D and 3D Hydrogen-Bonded Architectures Containing Cyclophane-Type Motifs. Crystal Growth and Design, 9: 1575-1583.

Sheldrick GM, 2008. A Short History of SHELX. Acta Crystallographica A64: 112-122.

Sheldrick GM, 2015. Crystal Structure Refinement with SHELXL. Acta Crystallographica Section C Structural Chemistry, 71: 3-8.

Sheldrick GM, SADABS V2008/1, University of Göttingen, Germany.

Tan YS, Sudlow, AL, Molloy KC, Morishima Y, Fujisawa K, Jackson WJ, Henderson W, Halim SNBA, Ng SW and Tiekink ERT, 2013. Supramolecular İsomerism in A Cadmium Bis(Nhydroxyethyl, N-isopropyldithiocarbamate) Compound: Physiochemical Characterization of Ball $(\mathrm{n}=2)$ and Chain $(\mathrm{n}=\infty)$ forms of $\left\{\mathrm{Cd}\left[\mathrm{S}_{2} \mathrm{CN}(\mathrm{iPr}) \mathrm{CH}_{2} \mathrm{CH}_{2} \mathrm{OH}\right]_{2} \cdot\right.$ solvent $\}$. Crystal Growth and Design, 13: 3046-3056.

SAINT V7.60A, Bruker-AXS, 2008. Inc. Madison, Wisconsin, USA.

Whyte GF, Vilar R and Woscholski R, 2013. Molecular Recognition with Boronic Acids-Applications in Chemical Biology. Journal of Chemical Biology, 6: 161-174.

Yahsi Y, Gungor E and Kara H, 2015. Chlorometallate-Pyridinium Boronic Acid Salts for Crystal Engineering: Synthesis of 1D, 2D and 3D Hydrogen Bond Networks. Crystal Growth and Design, 15: 2652-2660.

Yang W, Gao X and Wang B, 2003. Boronic Acid Compounds as Potential Pharmaceutical Agents. Medicinal Reserarch Reviews, 23: 346-368. 